\title{
Production and Optimization of Alkaline Protease in Submerged Fermentation by Streptomyces rochei NRC 24
}

\author{
M. A. Farid, N.A. Abdallah*, Nayera A. M. Abdelwahed \\ and Asmaa I. El Shazly \\ Natural \& Microbial Products Department, National Research \\ Center and * Microbiology Department, Faculty of Science, Ain \\ Shams University, Cairo, Egypt.
}
T HE PURPOSE of the present research was to study the production of extracellular alkaline protease by a local isolate, Streptomyces rochei NRC 24, under submerged fermentation (SF) conditions. The isolate exhibited maximum enzyme production with fermentation medium composed of peptone, glucose, $\mathrm{K}_{2} \mathrm{HPO}_{4}$, $\mathrm{MgSO}_{4} \cdot 7 \mathrm{H}_{2} \mathrm{O}, \mathrm{NaCl}$, and $\mathrm{CaCl}_{2}$. The studies on environmental parameters revealed that maximum level of alkaline protease production $(220.92 \mathrm{U} / \mathrm{ml})$ was achieved during stationary phase of $S$. rochei NRC 24 with optimum initial $\mathrm{pH} 9$, inoculum size of $2 \%$ from stock spore suspension $\left(5.6 \times 10^{6}\right.$ spores $\left./ \mathrm{ml}\right)$, and with a culture volume of $75 \mathrm{ml}$ in $250 \mathrm{ml}$ Erlenmeyer flasks under shaking conditions of $200 \mathrm{rpm}$. Of different nitrogen sources, casein and peptone with $0.4 \%$ of each proved to achieve maximum level of enzyme production. Screening experiments on medium components showed that the presence of peptone, glucose, $\mathrm{MgSO}_{4} .7 \mathrm{H}_{2} \mathrm{O}, \mathrm{NaCl}$ and $\mathrm{CaCl}_{2}$ were essential for alkaline protease production. The absence of $\mathrm{K}_{2} \mathrm{HPO}_{4}$ from the medium did not totally influence the enzyme production.

Based on these results, De Meo's fractional factorial design was applied to find out the optimal conditions for maximal alkaline protease production. Optimization of the medium was carried out in three steps and Streptomyces rochei NRC 24 grew in the optimized medium producing $555.61 \mathrm{U} / \mathrm{ml}$ compared to the growth of the strain on the basal medium before optimization $(224 \mathrm{U} / \mathrm{ml})$.

Keywords: Streptomyces rochei NRC 24, Alkaline protease, productin, optimization, De Meo's fractional factorial design.

Proteases are among the most important industrial enzymes, accounting for nearly $60 \%$ of the industrial market in the world (Mitra et al., 1996). The inability of plant and animal proteases to meet current world demands has led to an increased interest in microbial proteases (Rao et al., 1998). Alkaline proteases are robust enzymes with considerable industrial potential (Elibol \& Moreira, 2005). These enzymes are used in the detergent industry, leather processing, silver recovery, medical purposes, food processing, feed and chemical industries as well as waste treatment (Gupta et al., 2002). 
Microorganisms represent an attractive source of proteases as they can be cultured in large quantities in a relatively short time by established fermentation methods, and they produce an abundant, regular supply of the desired product. Furthermore, microbial proteins have a longer shelf life and can be stored under less than ideal conditions for weeks without significant loss of activity. In general, microbial proteases are extracellular in nature and are directly secreted into the fermentation broth by the producer, thus simplifying downstream processing of the enzyme compared to proteases obtained from plants and animals. The ability of some actinomycetes to produce various enzymes may be an attractive phenomenon because they are nutritionally quite versatile, and most of them produce extracellular hydrolytic enzymes. (Gupta et al., 1995). Streptomyces are great producers of proteolytic enzymes (Yeoman \& Edwards, 1997). Streptomyces species-producing proteases include $S$. sp. CN902, $S$. fungicidicus MML1614 and S. albidflavus (Lazim, 2009; Ramesh et al., 2009 and Abdel Aziz, 2011).

Extracellular protease production in microorganisms is strongly influenced by media components e.g. variation in $\mathrm{C} / \mathrm{N}$ ratio, presence of some easily metabolizable sugars (Beg et al., 2002), and metal ions (Varela et al., 1996). Optimization of the fermentation medium through statistical approaches has been used recently by research and process engineers to increase the yields of alkaline proteases with respect to their industrial requirements (Gupta et al., 2002). De Meo's fractional factorial design could be used as a valuable tool for rapid evaluation of the effect of different concentrations of medium constituents. This method provides indications about the concentration of each constituent and how it tends to affect cell growth, end product formation and specific activity. Meanwhile, this statistical design reduces the number of experiments needed and considers the interaction among variables (De Meo et al., 1985). In the present work, an effort was made to maximize alkaline protease production by $S$. rochei NRC 24 strain, which was isolated from Egyptian soil in shake flask culture. The optimization steps were performed as follows: (1) Manipulating the variation of nutritional components and culture conditions; (2) De Meo's fractional factorial design was employed to optimize the fermentation parameters for the improvement of alkaline protease production by S. rochei NRC 24.

\section{Materials and Methods}

\section{Microorganism}

Streptomyces rochei NRC 24 was isolated from an Egyptian soil using serial dilution method (Basavaraj et al., 2010). The isolate was identified using $16 \mathrm{~S}$ rDNA with the help of Mubarak City for Scientific Research \& Technology Applications, Alexandria, Egypt, and was used as a producer of alkaline protease.

The strain was maintained on actinomycete isolation agar medium composed of (g/l) sodium caseinate, 2.0; asparagine, 0.1; sodium propionate, 4; dipotassium phosphate, 0.5; magnesium sulfate, 0.1 ; ferrous sulfate, 0.001 , agar, $25 ; \mathrm{pH}, 8$.

Egypt. J. Microbiol. 47 (2012) 


\section{Fermentation conditions}

The batch submerged fermentation was carried out in $250 \mathrm{ml}$ Erlenmeyer flasks. Each flask contained $50 \mathrm{ml}$ of fermentation medium. Every $50 \mathrm{ml}$ of fermentation medium was inoculated with $1 \mathrm{ml}$ spore suspension $\left(5.6 \times 10^{6}\right.$ spores $/ \mathrm{ml}$ ) and incubated on a rotary shaker at $200 \mathrm{rpm}$ at $28 \pm 2{ }^{\circ} \mathrm{C}$. The culture broth from each flask was filtered by Whatmann filter paper (No. 1) to separate the Streptomyces cells from the culture medium. The final $\mathrm{pH}$, extracellular alkaline protease activity, protein content, and cell dry weight were determined in the culture filtrate. Experiments were carried out in triplicate; the reported results are the average values with standard deviations.

\section{Environmental and nutritional factors affecting cell growth and alkaline} protease production

Preliminary experiments were carried out using one factor-at a time for the enzyme production by $S$. rochei NRC 24 . Seven fermentation media (Table 1) were used to evaluate the production of alkaline protease in submerged fermentation by S. rochei NRC 24 (Ramesh et al., 2009), incubation time (1-7 days) (Mashhadi-Karim et al., 2011) and the initial $\mathrm{pH}$ of the selected medium which was varied from 5 to 11 adjusted by $0.1 \mathrm{~N} \mathrm{NaOH}$ or $0.1 \mathrm{~N} \mathrm{HCl}$ (Uyar et al., 2011). Additionally, the effect of inoculum size, prepared from five slants of seven days old culture, was studied using different spore suspensions (1, 2, 3, 4 and 6 $\% \mathrm{v} / \mathrm{v}$ ) (Lazim et al., 2009). To investigate the effect of aeration on alkaline protease production two different experiments were carried out. The first experiment included different agitation speeds (100, 150 and $200 \mathrm{rpm}$ ) (Sepahy \& Jabalameli, 2011) and the second one was set at the selected agitation speed using different medium volumes $(25,50,75$ and $100 \mathrm{ml} / 250 \mathrm{ml}$ conical flask) (Abdel-Aziz et al., 2011). Nitrogen sources including casein, whey, skimmed milk, soybean meal, soy milk, soy flour, wheat flour, and oat flakes were used at equivalent amounts of nitrogen content to peptone in the selected medium (Hames-Kocabas \& Uzel, 2007). Another experiment was also conducted using different concentrations of the most suitable nitrogen source (Ahmed et al., 2010). In order to arrive at the set of conditions for maximum alkaline protease production by $S$. rochei NRC 24 seven different preparations of the modified Protease Production Broth (PPB) medium were investigated. In each preparation, one medium component was omitted except for one preparation that contained all medium components used as a control.

Optimization of alkaline protease production using a statistical design

The purpose of the present study was to determine the influence of the concentrations of the culture medium components and the best fermentation conditions together for the maximum alkaline protease production from $S$. rochei NRC 24 using a fractional factorial experimental design described by De Meo et al. (1985). The experimental design was developed to find out the influence of nutrients such as casein (A), glucose (B), $\mathrm{MgSO}_{4} \cdot 7 \mathrm{H}_{2} \mathrm{O}(\mathrm{C}), \mathrm{NaCl}$ (D), $\mathrm{CaCl}_{2}$ (E) and fermentation conditions like initial $\mathrm{pH}(\mathrm{F})$, and medium volume (G). This method allows the improvement of the medium composition of seven 
different experiments and each column represents a different parameter. For each parameter, high $(\mathrm{H})$ and low $(\mathrm{L})$ concentrations were tested (Table 3). For the evaluation of the effect of each factor, the coefficients alkaline protease activity $\left(\mathrm{C}_{\mathrm{p}}\right)$, cell dry weight $\left(\mathrm{C}_{\mathrm{x}}\right)$, and specific activity $\left(\mathrm{C}_{\mathrm{s}}\right)$ were calculated as follows: if $\mathrm{P}$ is the alkaline protease activity $(\mathrm{U} / \mathrm{ml}), \mathrm{X}$ is the cell dry weight $(\mathrm{g} / \mathrm{l})$ and $\mathrm{S}$ is the specific activity of alkaline protease $(\mathrm{U} / \mathrm{mg})$, the coefficients $\mathrm{C}_{\mathrm{p}}, \mathrm{C}_{\mathrm{x}}$ and $\mathrm{C}_{\mathrm{s}}$ relating to each of the seven parameters are given by:

$\mathrm{C}_{\mathrm{pj}}=1 / 8 \times\left[\sum \mathrm{i}^{8}={ }_{1} \mathrm{Aj} \times \mathrm{P}_{\mathrm{i}}\right]$

$\mathrm{C}_{\mathrm{xj}}=1 / 8 \times\left[\sum \mathrm{i}^{8}={ }_{1} \mathrm{Aj} \times \mathrm{X}_{\mathrm{i}}\right]$

$\mathrm{C}_{\mathrm{sj}}=1 / 8 \times\left[\sum \mathrm{i}^{8}={ }_{1} \mathrm{Aj} \times \mathrm{S}_{\mathrm{i}}\right]$

Here, $\mathrm{Aj}$ means either high $(\mathrm{H})$ or low $(\mathrm{L})$ level in experimental run $\mathrm{i}$. If the calculated coefficient has a positive value, it means that the particular parameter has a positive effect at its high level.

TABLE 1. Composition of seven fermentation media.

\begin{tabular}{|c|c|}
\hline $\begin{array}{l}\text { Medium } \\
\text { No. }\end{array}$ & $\begin{array}{l}\text { Composition } \\
\text { (g/l) }\end{array}$ \\
\hline 2 & $\begin{array}{l}\text { Casein, 20; Glucose, 1.0; } \mathrm{KH}_{2} \mathrm{PO}_{4}, 1.5 ; \mathrm{Na}_{2} \mathrm{HPO}_{4}, 1.5 ; \text { Distilled water, } 1000 \mathrm{ml} ; \mathrm{pH} \text {, } \\
9 \text { (Chahal \& Nanda, 1975). }\end{array}$ \\
\hline 3 & $\begin{array}{l}\left(\mathrm{NH}_{4}\right)_{2} \mathrm{SO}_{4}, 1 ; \mathrm{KH}_{2} \mathrm{PO}_{4}, 0.5 ; \mathrm{CaCO}_{3}, 1 ; \mathrm{NaCl}, 1 ; \mathrm{MgSO}_{4} .7 \mathrm{H}_{2} \mathrm{O}, 1 ; \text { Glucose, } 10 ; \\
\text { Peptone, } 0.1 ; \text { Distilled water, } 1000 \mathrm{ml} ; \mathrm{pH}, 9 \text { (Ahmed, 1994). }\end{array}$ \\
\hline 4 & $\begin{array}{l}\text { Peptone, 4; Glucose, } 10 ; \mathrm{K}_{2} \mathrm{HPO}_{4}, 0.5 ; \mathrm{MgSO}_{4} .7 \mathrm{H}_{2} \mathrm{O}, 0.5 ; \mathrm{NaCl}, 0.5 ; \mathrm{CaCl}_{2}, 0.5 \text {; } \\
\text { Distilled water, } 1000 \mathrm{ml} ; \mathrm{pH}, 9 \text { (Ramesh et al., 2009). }\end{array}$ \\
\hline 5 & $\begin{array}{l}\mathrm{KH}_{2} \mathrm{PO}_{4}, 1.5 ; \mathrm{K}_{2} \mathrm{HPO}_{4}, 9.0 ; \mathrm{MgSO}_{4} .7 \mathrm{H}_{2} \mathrm{O}, 0.2 ; \mathrm{CaCl}_{2}, 0.05 ; \\
\mathrm{MnSO}_{4}, 0.01 ; \mathrm{ZnSO}_{4} .7 \mathrm{H}_{2} \mathrm{O}, 0.001 ; \text { Yeast extract , } 0.01 ; \text { Wheat bran, } 0.25 \text {; Distilled } \\
\text { water, } 1000 \mathrm{ml} ; \mathrm{pH}, 9 \text { (Nascimento } \text { et al., 2005). }\end{array}$ \\
\hline 6 & $\begin{array}{l}\text { Peptone, 10; } \mathrm{Sucrose}_{10} \mathrm{~K}_{2} \mathrm{HPO}_{4}, 0.5 ; \mathrm{MgSO}_{4} .7 \mathrm{H}_{2} \mathrm{O}, 0.5 \\
\mathrm{NaCl}, 0.5 ; \mathrm{CaCl}_{2}, 0.5 ; \text { Distilled water, } 1000 \mathrm{ml} ; \mathrm{pH}, 9 \text { (Ramesh et al., 2009). }\end{array}$ \\
\hline 7 & $\begin{array}{l}\text { Maltose, 10; Yeast extract , 2; Meat extract , 1; Distilled water, } 1000 \mathrm{ml} ; \mathrm{pH}, 9 \\
\text { (Ramesh } \text { et al., 2009). }\end{array}$ \\
\hline 8 & $\begin{array}{l}\text { Glucose, } 10 ; \text { Casein, 5; Yeast extract, } 5 ; \mathrm{K}_{2} \mathrm{HPO}_{4}, 1 ; \mathrm{MgSO}_{4} .7 \mathrm{H}_{2} \mathrm{O}, 0.2 ; \mathrm{Na}_{2} \mathrm{CO}_{3}, 10 \text {; } \\
\text { Distilled water, } 1000 \mathrm{ml} ; \mathrm{pH}, 9 \text { (Tsujibo } \text { et al., } 1990 \text { ). }\end{array}$ \\
\hline
\end{tabular}

Assay of alkaline protease activity

Alkaline protease was determined using casein as a substrate according to the method reported by Gessesse \& Gashe (1997), with some modifications. One unit of protease activity was defined as the amount of enzyme that released $1 \mu \mathrm{g}$ tyrosine per min under the assay condition.

\section{Estimation of the extracellular protein}

The protein content of the crude enzyme source was determined by the method of Lowry et al. (1951) using bovine serum albumin as a standard.

Egypt. J. Microbiol. 47 (2012) 
TABLE 2. A fractional factorial experimental design by De Meo et al. (1985).

\begin{tabular}{|c|c|c|c|c|c|c|c|}
\hline \multirow{2}{*}{$\begin{array}{c}\text { Expt. } \\
\text { run }\end{array}$} & \multicolumn{7}{|c|}{ Factors } \\
\cline { 2 - 9 } & A & B & C & D & E & F & G \\
\hline 1 & L & H & H & H & L & L & L \\
\hline 2 & H & H & L & L & L & L & H \\
\hline 3 & H & L & H & L & L & H & L \\
\hline 4 & L & L & L & H & L & H & H \\
\hline 5 & H & L & L & H & H & L & L \\
\hline 6 & L & L & H & L & H & L & H \\
\hline 7 & L & H & L & L & H & H & L \\
\hline 8 & H & H & H & H & H & H & H \\
\hline
\end{tabular}

TABLE 3. Low and high levels of medium variables used in the three optimization steps for alkaline protease production.

\begin{tabular}{|c|c|c|c|c|c|c|c|}
\hline \multirow{2}{*}{\multicolumn{2}{|c|}{ Variable value }} & \multicolumn{2}{|c|}{ First step } & \multicolumn{2}{|c|}{ Second step } & \multicolumn{2}{|c|}{ Third step } \\
\hline & & \multirow{2}{*}{$\begin{array}{c}\text { Low level } \\
\text { (g/l) }\end{array}$} & \multirow{2}{*}{ 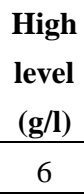 } & \multirow{2}{*}{$\begin{array}{c}\begin{array}{c}\text { Low } \\
\text { level } \\
(\mathrm{g} / \mathrm{l})\end{array} \\
2\end{array}$} & \multirow{2}{*}{ 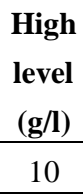 } & \multirow{2}{*}{ 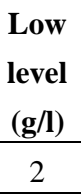 } & \multirow{2}{*}{ 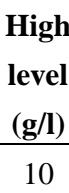 } \\
\hline A & Casein & & & & & & \\
\hline $\mathrm{B}$ & Glucose & 2 & 4 & 2 & 10 & 2 & 4 \\
\hline $\mathrm{C}$ & $\mathrm{MgSO} 4.7 \mathrm{H}_{2} \mathrm{O}$ & 0.2 & 0.8 & 0.2 & 2 & 0.2 & 0.8 \\
\hline $\mathrm{D}$ & $\mathrm{NaCl}$ & 0.2 & 0.8 & 0.2 & 2 & 0.2 & 0.8 \\
\hline $\mathrm{E}$ & $\mathrm{CaCl}_{2}$ & 0.2 & 0.8 & 0.2 & 2 & 0.2 & 0.8 \\
\hline $\mathrm{F}$ & Initial $\mathrm{pH}$ & 8 & 10 & 8 & 10 & 8 & 10 \\
\hline G & Medium volume & 50 & 100 & 50 & 100 & 50 & 100 \\
\hline
\end{tabular}

\section{Results and Discussion}

Influence of fermentation parameters on alkaline protease production

Effect of different fermentation media on alkaline protease production

Medium No. 4 proved to be the most suitable for maximal alkaline protease production (Table 4 \& Fig. 1). Out of seven fermentation media used, it exhibited the highest alkaline protease production $(230.52 \mathrm{U} / \mathrm{ml})$ with maximum specific activity $(81.75 \mathrm{U} / \mathrm{mg})$ and yield coefficient of about $147.64 \mathrm{U} / \mathrm{g}$. The inability of $S$. rochei NRC 24 to produce extracellular alkaline protease in some of the tested production media may be due to one or more of several factors including high viscosity of the fermentation broth, which may lead the culture medium (as in media No. 2 and 3) to become difficult to agitate and supply with 
oxygen (Tanaka, 1982). High phosphate concentration as exhibited in Media No. 5 (Mehta et al., 2006) and high concentration of carbon and/or nitrogen source in the fermentation broth as in Media No. 6, 7 and 8 (Vinogrodova et al., 2003). In addition, the presence of ammonium sulfate as a nitrogen source (as in Medium No. 3) usually produces acidic conditions when ammonium ion is utilized and a free acid is liberated (Stanbury et al., 1995). This fact was confirmed by estimating the final $\mathrm{pH}$ of the fermentation broth and it was found that the initial $\mathrm{pH}$ dropped from 9 to 6 at the end of fermentation process.

TABLE 4. Effect of different fermentation media on the production of $S$. rochei NRC 24 alkaline protease.

\begin{tabular}{|c|c|c|c|c|c|c|c|}
\hline \multirow{2}{*}{$\begin{array}{c}\text { Medi- } \\
\text { um }\end{array}$} & $\begin{array}{c}\text { Incubation } \\
\text { period } \\
\text { (days) }\end{array}$ & Final pH & $\begin{array}{c}\text { Cell dry } \\
\text { weight } \\
(\mathbf{g} / \mathbf{l})\end{array}$ & $\begin{array}{c}\text { Soluble } \\
\text { protein } \\
(\mathbf{m g} / \mathbf{m l})\end{array}$ & $\begin{array}{c}\text { Activity } \\
(\mathbf{U} / \mathbf{m l})\end{array}$ & $\begin{array}{c}\text { Specific } \\
\text { activity } \\
(\mathbf{U} / \mathbf{m g})\end{array}$ & $\begin{array}{c}\text { Yield } \\
\text { (U/g) }\end{array}$ \\
\hline 2 & 3 & $8.6 \pm 0$ & $4.45 \pm 0.58$ & $9.7 \pm 2.29$ & $166.48 \pm 7.57$ & $17.16 \pm 2.19$ & $37.41 \pm 5.71$ \\
\cline { 2 - 8 } & 4 & $8.7 \pm 0.05$ & $5.49 \pm 1.02$ & $9.54 \pm 1.27$ & $217.89 \pm 45.43$ & $22.75 \pm 2.82$ & $48.33 \pm 14.06$ \\
\hline \multirow{2}{*}{3} & 3 & $6.3 \pm 0.06$ & $3.12 \pm 0.61$ & $0.45 \pm 0.33$ & $0.0 \pm 0$ & $0.0 \pm 0$ & $0.0 \pm 0$ \\
\cline { 2 - 8 } & 4 & $6.1 \pm 0.16$ & $2.97 \pm 0.29$ & $0.95 \pm .014$ & $3.36 \pm 3.56$ & $3.54 \pm 4.14$ & $1.13 \pm 1.12$ \\
\hline 4 & 3 & $8.3 \pm 0.078$ & $1.31 \pm 1.81$ & $3.42 \pm 0.26$ & $195.55 \pm 6.41$ & $57.18 \pm 2.64$ & $149.28 \pm 2.25$ \\
\cline { 2 - 8 } & 4 & $8.6 \pm 0.092$ & $1.32 \pm 1.05$ & $2.82 \pm 0.33$ & $230.52 \pm 4.24$ & $81.75 \pm 4.16$ & $147.64 \pm 13.23$ \\
\hline 5 & 3 & $8.1 \pm 0.092$ & $15.40 \pm 6.93$ & $2.51 \pm 0.3$ & $0.0 \pm 0$ & $0.0 \pm 0$ & $0.0 \pm 0$ \\
\cline { 2 - 8 } & 4 & $8.2 \pm 0.37$ & $15.88 \pm 6.12$ & $2.82 \pm 0.59$ & $0.0 \pm 0$ & $0.0 \pm 0$ & $0.0 \pm 0$ \\
\hline 6 & 3 & $8.6 \pm 0.092$ & $3.07 \pm 1.75$ & $4.01 \pm 1.2$ & $0.0 \pm 0$ & $0.0 \pm 0$ & $0.0 \pm 0$ \\
\cline { 2 - 8 } & 4 & $8.5 \pm 0.064$ & $4.54 \pm 1.04$ & $2.96 \pm 0.19$ & $0.0 \pm 0$ & $0.0 \pm 0$ & $0.0 \pm 0$ \\
\hline 7 & 3 & $8.1 \pm 0.33$ & $1.90 \pm 0.6$ & $1.53 \pm 0.57$ & $2.36 \pm 2.5$ & $1.54 \pm 2.21$ & $1.24 \pm 1.07$ \\
\hline \multirow{2}{*}{8} & 4 & $8.1 \pm 0.07$ & $1.13 \pm 0.17$ & $2.67 \pm 0.56$ & $4.88 \pm 5.17$ & $1.83 \pm 1.68$ & $4.32 \pm 4.13$ \\
\cline { 2 - 8 } & 3 & $9.8 \pm 0.12$ & $2.51 \pm 0.86$ & $3.89 \pm 1.75$ & $1.35 \pm 1.41$ & $0.35 \pm 0.28$ & $0.54 \pm 0.75$ \\
\hline \multirow{2}{*}{5} & 4 & $9.8 \pm 0.16$ & $2.49 \pm 0.49$ & $7.05 \pm 0.28$ & $0.6 \pm 0.63$ & $0.09 \pm 0.09$ & $0.24 \pm 0.3$ \\
\hline
\end{tabular}

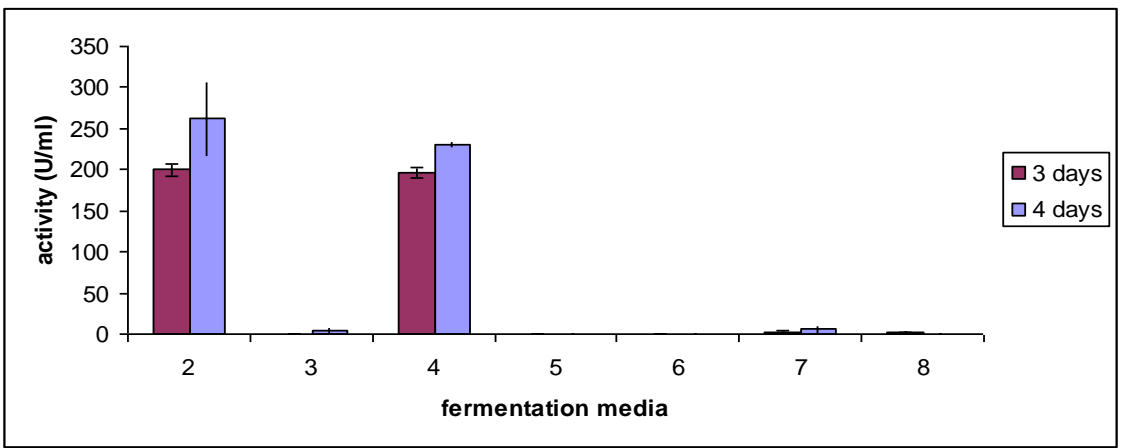

Fig. 1. Effect of different fermentation medium on alkaline protease production by $S$. rochei NRC 24.

Egypt. J. Microbiol. 47 (2012) 


\section{Effect of incubation time on alkaline protease production}

Cell growth, soluble protein and enzyme activity of alkaline protease were influenced by the fermentation time (Table $5 \&$ Fig. 2). The strain grew well during the fermentation time and mycelial growth increased with the increase of fermentation time. The cell dry weight increased gradually from about $1.06 \mathrm{~g} / \mathrm{l}$ after one day incubation to reach its maximum value of $1.32 \mathrm{~g} / \mathrm{l}$ after 4 days, after that the mycelial growth gradually decreased. However, the volumetric alkaline protease increased exponentially from one day to four days incubation where it reached its maximum value of 220.92 $\mathrm{U} / \mathrm{ml}$. After that the activity decreased gradually to reach a minimum value of $31.09 \mathrm{U} / \mathrm{ml}$ after seven days. The maximum specific enzyme activity and maximal yield coefficient were recorded after four days. This result is similar to these reported by De Azeredo et al. (2006a, b) for Streptomyces sp. 594; Mitsuiki et al. (2002) for Nocardiopsis sp. TOA-1 and Dixit \& Pant (2000) for Nocardiopsis sp. NCIM 5124. The results also showed that at further incubation from four days, the enzyme activity chronically with the biomass drastically decreased to become $31.09 \mathrm{U} / \mathrm{ml}$ and $0.66 \mathrm{~g} / \mathrm{l}$, respectively after seven days incubation. That marked decline could be because after four days incubation, the microorganism was in its declining phase in which the aeration rate cannot keep up with the culture oxygen consumption rate, so the concentration of dissolved oxygen drops, the carbon source, or any other nutrient, may be consumed to the point where its availability limits growth, toxins may accumulate and inhibit growth or metabolic waste products accumulate (Roach et al., 2008).

TABLE 5. Effect of incubation period on the production of $S$. rochei NRC 24 alkaline protease.

\begin{tabular}{|c|c|c|c|c|c|c|}
\hline $\begin{array}{c}\text { Incubation } \\
\text { period } \\
(\mathbf{d a y s})\end{array}$ & Final pH & $\begin{array}{c}\text { Cell dry } \\
\text { weight } \\
(\mathbf{g} / \mathbf{l})\end{array}$ & $\begin{array}{c}\text { Protein } \\
(\mathbf{m g} / \mathbf{m l})\end{array}$ & $\begin{array}{c}\text { Activity } \\
(\mathbf{U} / \mathbf{m l})\end{array}$ & $\begin{array}{c}\text { Specific } \\
\text { activity } \\
(\mathbf{U} / \mathbf{m g})\end{array}$ & $\begin{array}{c}\text { Yield } \\
(\mathbf{U} / \mathbf{g})\end{array}$ \\
\hline 1 & $7.6 \pm 0.12$ & $1.06 \pm 0.04$ & $2.43 \pm 0.35$ & $11.23 \pm 1.87$ & $4.62 \pm 0.47$ & $10.59 \pm 1.34$ \\
\hline 2 & $8.0 \pm 0.02$ & $1.29 \pm 0.18$ & $3.17 \pm 0.14$ & $175.34 \pm 9.61$ & $55.31 \pm 1.94$ & $135.92 \pm 16.39$ \\
\hline 3 & $8.2 \pm 0$ & $1.31 \pm 0.03$ & $3.42 \pm 0.12$ & $200.86 \pm 37.69$ & $58.73 \pm 10.09$ & $153.33 \pm 32.6$ \\
\hline 4 & $8.3 \pm 0.08$ & $1.32 \pm 0.04$ & $2.82 \pm 0.28$ & $220.92 \pm 1.61$ & $78.34 \pm 4.12$ & $168.64 \pm 9.21$ \\
\hline 5 & $8.3 \pm 0.035$ & $0.76 \pm 0.14$ & $3.67 \pm 0.47$ & $112.99 \pm 9.36$ & $30.79 \pm 3.2$ & $148.67 \pm 8.02$ \\
\hline 6 & $8.4 \pm 0.05$ & $0.73 \pm 0.13$ & $3.24 \pm 0.45$ & $112.95 \pm 19.24$ & $34.86 \pm 3.71$ & $154.73 \pm 13.99$ \\
\hline 7 & $8.3 \pm 0.03$ & $0.66 \pm 0.10$ & $3.51 \pm 0.69$ & $31.09 \pm 0.54$ & $8.86 \pm 0.99$ & $47.11 \pm 4.34$ \\
\hline
\end{tabular}




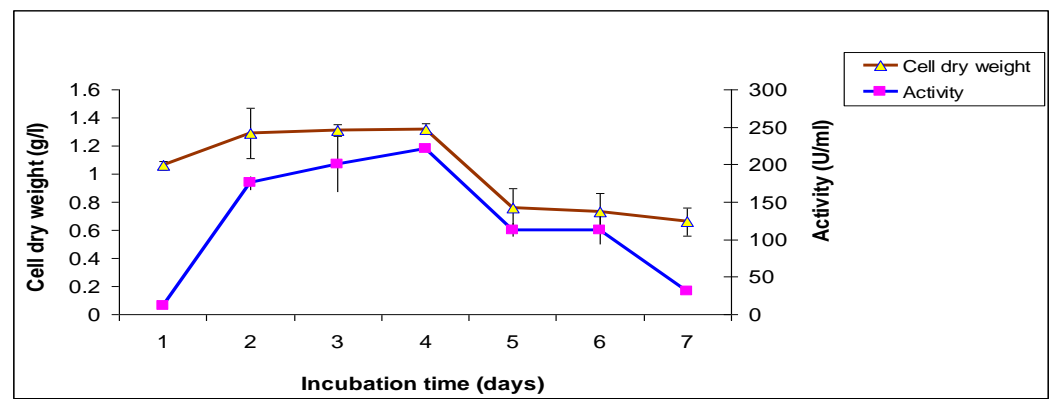

Fig. 2. Effect of different incubation time on alkaline protease production by $S$. rochei NRC 24.

Effect of initial $\mathrm{pH}$ value on alkaline protease production

Production of $S$. rochei NRC 24 alkaline protease was considerably affected by the initial $\mathrm{pH}$ value of the fermentation medium (Table 6 and Fig. 3). Although the strain was able to produce the enzyme over a wide $\mathrm{pH}$ range (6-11), pH 9 was the most favorable for alkaline protease production $(244 \mathrm{U} / \mathrm{ml})$. Above or below $\mathrm{pH} 9$, the results showed a gradual decrease in enzyme production except for the initial $\mathrm{pH} 6$, a protease activity of $208 \mathrm{U} / \mathrm{ml}$ was recorded. Concerning the cell mass, the microorganism grew well at all $\mathrm{pH}$ values and its growth ranged from 0.92 to $1.92 \mathrm{~g} / \mathrm{l}$. These results are similar to those reported by Dastager et al. (2008) for S. gulbargensis DSA 131; Thumar \& Singh (2007) for S. clavuligerus MIT-1 and Jayasree et al. (2009) for $S$. pulvereceus MTCC 8374. On the other hand, Kanekar et al. (2002) and Ahmed et al. (2008) reported maximal alkaline protease at $\mathrm{pH} 8$ by Arthrobacter ramosus and $S$. avermectinus NRRL B-8165, respectively. These results suggested that the $\mathrm{pH}$-dependent changes in the amount of enzyme production might have been due to $\mathrm{pH}$ control over the growth of bacteria or $\mathrm{pH}$-dependent control of protease gene expression (Young et al., 1996).

TABLE 6. Effect of initial pH value on the production of $S$. rochei NRC 24 alkaline protease.

\begin{tabular}{|c|c|c|c|c|c|c|}
\hline $\begin{array}{c}\text { Initial } \\
\mathbf{p H}\end{array}$ & Final pH & $\begin{array}{c}\text { Cell dry } \\
\text { weight } \\
(\mathbf{g} / \mathbf{l})\end{array}$ & $\begin{array}{c}\text { Protein } \\
(\mathbf{m g} / \mathbf{m l})\end{array}$ & $\begin{array}{c}\text { Activity } \\
(\mathbf{U} / \mathbf{m l})\end{array}$ & $\begin{array}{c}\text { Specific } \\
\text { activity } \\
(\mathbf{U} / \mathbf{m g})\end{array}$ & $\begin{array}{c}\text { Yield } \\
(\mathbf{U} / \mathbf{g})\end{array}$ \\
\hline 5 & $7.9 \pm 0.08$ & $0.92 \pm 0.034$ & $2.59 \pm 0.43$ & $0.0 \pm 0$ & $0.0 \pm 0$ & $0.0 \pm 0$ \\
\hline 6 & $8.2 \pm 0.08$ & $1.2 \pm 0.06$ & $2.47 \pm 0.26$ & $208.59 \pm 9.61$ & $84.45 \pm 6.16$ & $173.825 \pm 5.2$ \\
\hline 7 & $8.2 \pm 0$ & $1.06 \pm 0.05$ & $2.49 \pm 0.23$ & $80.52 \pm 9.62$ & $32.34 \pm 4.79$ & $75.96 \pm 10.23$ \\
\hline 8 & $8.3 \pm 0.05$ & $1.13 \pm 0.2$ & $1.38 \pm 0.26$ & $93.03 \pm 17.37$ & $67.41 \pm 19.11$ & $82.33 \pm 22.8$ \\
\hline $9 *$ & $8.2 \pm 0.01$ & $1.26 \pm 0.3$ & $1.89 \pm 0.73$ & $224 \pm 15.78$ & $118.52 \pm 6.19$ & $177.78 \pm 0.35$ \\
\hline 10 & $8.3 \pm 0$ & $1.92 \pm 0.46$ & $3.35 \pm 1.06$ & $132.67 \pm 2.67$ & $39.6 \pm 7.32$ & $69.1 \pm 9.74$ \\
\hline 11 & $8.6 \pm 0.02$ & $1.24 \pm 0.08$ & $3.19 \pm 0.17$ & $78.04 \pm 1.06$ & $24.46 \pm 0.06$ & $62.94 \pm 2.18$ \\
\hline$*$ Control & & \multicolumn{3}{|l}{} & &
\end{tabular}

Egypt. J. Microbiol. 47 (2012) 


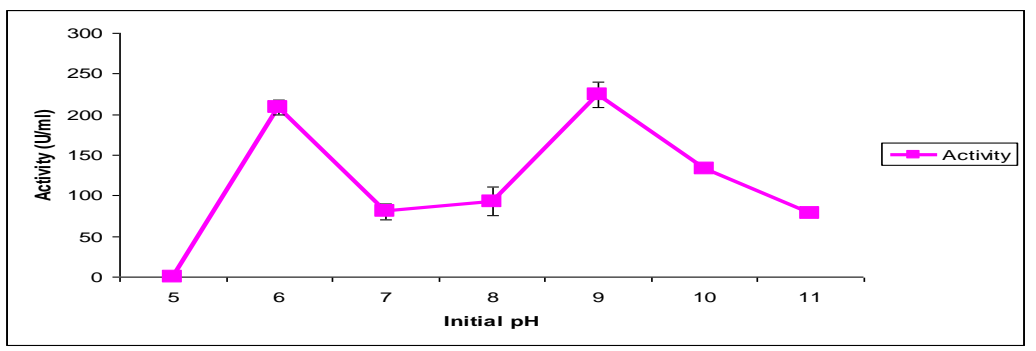

Fig. 3. Effect of initial pH on alkaline protease production by $S$. rochei NRC 24 .

Effect of inoculum size on alkaline protease production

The present experiment was undertaken to investigate the effect of inoculum size on the production of alkaline protease by $S$. rochei NRC 24. Fermentation broth inoculated with $2 \%(\mathrm{v} / \mathrm{v})$ spore suspension of seven days old, with CFU of $5.6 \mathrm{x} 10^{6}$ spores/ $\mathrm{ml}$, showed the maximum alkaline protease activity $(244 \mathrm{U} / \mathrm{ml})$ and the lowest cell dry weight $(0.87 \mathrm{~g} / \mathrm{l})$ (Table 7 and Fig. 4). Increasing the inoculum size more than $2 \%(\mathrm{v} / \mathrm{v})$ resulted in a gradual decrease in the enzyme level. However, the increase in the inoculum size was accompanied by an increase in the cell dry mass (1.26- $1.4 \mathrm{~g} / \mathrm{l})$. Higher biomasses resulted in higher viscosity of the fermentation broths and as a consequence the culture media became difficult to agitate and supply with oxygen (Tanaka, 1982). That fact was supported by Rahman et al. (2005) who stated that high inoculum sizes may not necessarily give higher production yield as they could result in the lack of oxygen and nutrient depletion in the culture media. In this respect, similar results were reported by Kanekar et al. (2002) for A. ramosus and Bacillus alcalophilus.

TABLE 7. Effect of inoculum size on the production of $S$. rochei NRC 24 alkaline protease.

\begin{tabular}{|c|c|c|c|c|c|}
\hline $\begin{array}{c}\text { Inoculum size } \\
(\mathrm{ml} / \mathbf{1 0 0} \mathbf{~ m l})\end{array}$ & $\begin{array}{l}\text { Incubation } \\
\text { Time (days) }\end{array}$ & Final pH & $\begin{array}{c}\text { Cell dry } \\
\text { weight }(\mathrm{g} / \mathrm{l})\end{array}$ & $\begin{array}{l}\text { Protein } \\
(\mathrm{mg} / \mathrm{ml})\end{array}$ & $\begin{array}{c}\text { Activity } \\
\text { (U/ml) }\end{array}$ \\
\hline \multirow{5}{*}{1} & 1 & \multirow[b]{5}{*}{$8.4 \pm 0.0$} & \multirow[b]{5}{*}{$1.41 \pm 0.46$} & $0.28 \pm 0.24$ & $58.8 \pm 26.63$ \\
\hline & 2 & & & $0.64 \pm 0.21$ & $91.58 \pm 27.56$ \\
\hline & 3 & & & $1.4 \pm 0.61$ & $95.85 \pm 24.46$ \\
\hline & 4 & & & $0.79 \pm 0.08$ & $20.12 \pm 11.49$ \\
\hline & 5 & & & $0.38 \pm 0.09$ & $1.69 \pm 1.08$ \\
\hline \multirow{5}{*}{$2 *$} & 1 & \multirow[b]{5}{*}{$8.4 \pm 0.09$} & \multirow[b]{5}{*}{$0.87 \pm 0.24$} & $0.19 \pm 0.03$ & $98.82 \pm 29.75$ \\
\hline & 2 & & & $0.76 \pm 0.44$ & $185.28 \pm 40.85$ \\
\hline & 3 & & & $2.49 \pm 0.61$ & $200 \pm 33.2$ \\
\hline & 4 & & & $2.49 \pm 0.11$ & $224 \pm 10.08$ \\
\hline & 5 & & & $1.17 \pm 0.98$ & $60.48 \pm 4.69$ \\
\hline \multirow{5}{*}{4} & 1 & \multirow[b]{5}{*}{$8.2 \pm 0.09$} & \multirow[b]{5}{*}{$0.89 \pm 0.39$} & $0.38 \pm 0.12$ & $173.3 \pm 17.1$ \\
\hline & 2 & & & $1.7 \pm 1.44$ & $195.32 \pm 53.33$ \\
\hline & 3 & & & $2.48 \pm 1.73$ & $98.9 \pm 3.27$ \\
\hline & 4 & & & $0.53 \pm 0.14$ & $75.23 \pm 7.98$ \\
\hline & 5 & & & $0.51 \pm 0.28$ & $40.98 \pm 6.66$ \\
\hline \multirow{5}{*}{6} & 1 & \multirow[b]{5}{*}{$8.2 \pm 0.05$} & \multirow[b]{5}{*}{$1.26 \pm 0.12$} & $0.14 \pm 0.08$ & $99.2 \pm 27.07$ \\
\hline & 2 & & & $2.23 \pm 0.88$ & $154.79 \pm 69.0$ \\
\hline & 3 & & & $2.76 \pm 1.51$ & $137.09 \pm 41.72$ \\
\hline & 4 & & & $2.76 \pm 0.13$ & $91.77 \pm 26.29$ \\
\hline & 5 & & & $0.82 \pm 0.1$ & $69.1 \pm 25.28$ \\
\hline
\end{tabular}

*Control

$1 \mathrm{ml}$ Spore suspension contained $\sim 5.6 \times 10^{6}$ 


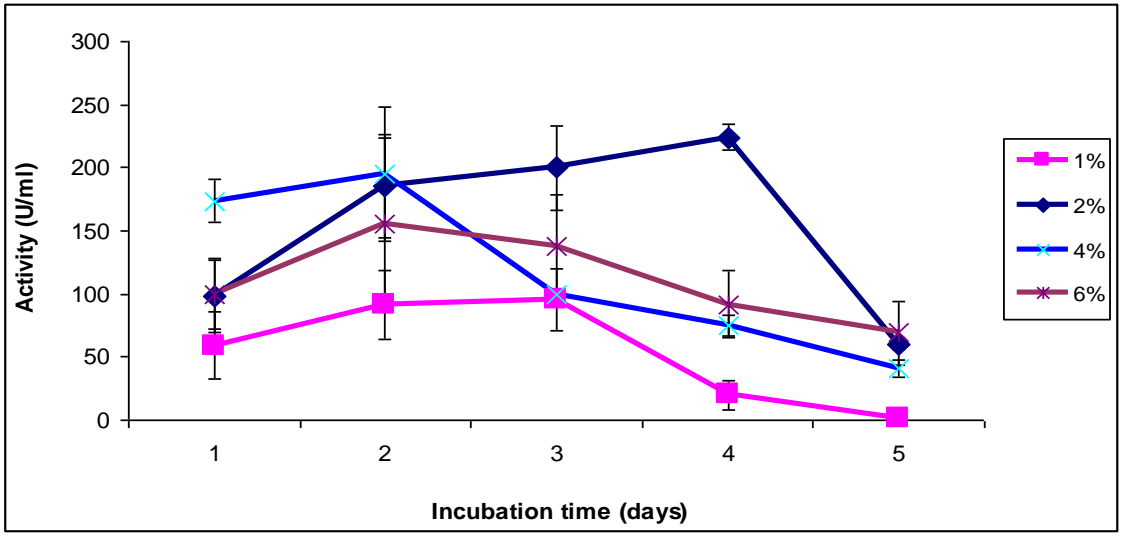

Fig. 4. Effect of inoculum size on the production of $S$. rochei NRC 24 alkaline protease.

Effect of aeration on alkaline protease production

In order to investigate the effect of aeration on alkaline protease production, two different experiments were carried out. These included different agitation speeds and different volumes of cultivation medium. The relation between cell growth and enzyme production as a function of different agitation speeds (100, 150 and $200 \mathrm{rpm}$ ) in shake flask was studied. Increasing the agitation speed increased cell dry weight, soluble protein and alkaline protease production (Table 8 \& Fig. 5). At agitation speed of 200rpm, maximum enzyme production $(244 \mathrm{U} / \mathrm{ml})$, cell dry weight $(1.26$ $\mathrm{g} / \mathrm{l})$ and soluble protein $(2.4 \mathrm{mg} / \mathrm{ml})$ were obtained. These results may owe to the fact that increasing the agitation speed (to a certain level to avoid shear stress) improves enzyme synthesis because it is able to maintain a significant dissolved oxygen level in the culture medium. For an optimal enzyme production, it is also necessary to reach a good mix of the culture broth because agitation produces a dispersion of air in the culture medium, homogenizes the temperature and the $\mathrm{pH}$, and improves transference rate of nutrients (Markl \& Bronnenmeier, 1985). In this respect, similar results were reported by Nascimento et al. (2005) for $S$. malaysiensis AMT-3; De Azeredo et al. (2006a, b) for Streptomyces sp. 594; Ramesh et al. (2009) for $S$. fungicidicus MML 1614 and Dixit \& Pant (2000) for Nocardiopsis sp. NCIM 5124.

TABLE 8. Effect of different agitation speeds on the production of $S$. rochei NRC 24 alkaline protease.

\begin{tabular}{|c|c|c|c|c|c|c|}
\hline $\begin{array}{c}\text { Agitation } \\
(\mathbf{r p m})\end{array}$ & Final pH & $\begin{array}{c}\text { Cell dry weight } \\
(\mathbf{g} / \mathbf{l})\end{array}$ & $\begin{array}{c}\text { Protein } \\
(\mathbf{m g} / \mathbf{m l})\end{array}$ & $\begin{array}{c}\text { Activity } \\
(\mathbf{U} / \mathbf{m l})\end{array}$ & $\begin{array}{c}\text { Specific } \\
\text { activity } \\
(\mathbf{U} / \mathbf{m g})\end{array}$ & $\begin{array}{c}\text { Yield } \\
(\mathbf{U} / \mathbf{g})\end{array}$ \\
\hline 100 & $8.3 \pm 0.04$ & $0.916 \pm 0.02$ & $1.88 \pm 0.49$ & $109.82 \pm 1.0$ & $58.41 \pm 5.32$ & $119.89 \pm 9.19$ \\
\hline 150 & $8.3 \pm 0.04$ & $1.17 \pm 0.19$ & $2.19 \pm 0.41$ & $147.27 \pm 4.72$ & $67.25 \pm 13.31$ & $125.87 \pm 3.93$ \\
\hline $200^{*}$ & $8.2 \pm 0.03$ & $1.26 \pm 0.05$ & $2.4 \pm 0.45$ & $224 \pm 17.73$ & $93.33 \pm 11.92$ & $177.78 \pm 15.53$ \\
\hline
\end{tabular}

Egypt. J. Microbiol. 47 (2012) 


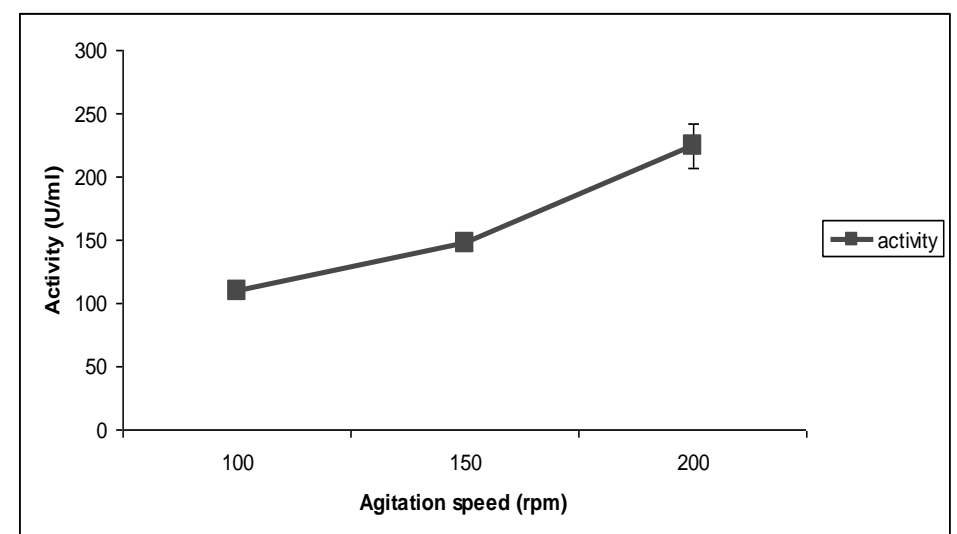

Fig. 5. Effect of different agitation speeds on the production of S.rochei NRC 24 alkaline protease.

The data (Table 9 and Fig. 6) also demonstrated that upon increasing medium volumes, from $25 \mathrm{ml} /$ flask to $100 \mathrm{ml} /$ flask, alkaline protease activity gradually increased and reached its maximal values of $224.16 \mathrm{U} / \mathrm{ml}$ in case of $75 \mathrm{ml}$ medium volume. Also, results showed that the volume of the fermentation medium more than $75 \mathrm{ml} /$ flask had a negative effect on the enzyme production. The cell dry weight decreased with the increase of medium volume. From the aforementioned data, agitation speed of $200 \mathrm{rpm}$ with medium volume of $75 \mathrm{ml} /$ flask achieved the microorganism's demand of oxygen at a sufficient rate for maximal alkaline protease production.

TABLE 9. Effect of medium volume on the production of $S$. rochei NRC 24 alkaline protease.

\begin{tabular}{|c|c|c|c|c|c|c|c|}
\hline $\begin{array}{c}\text { Volume of } \\
\text { the medium } \\
(\mathbf{m l / f l a s k})\end{array}$ & $\begin{array}{c}\text { Air: } \\
\text { medium } \\
\text { ratio } \\
(\mathbf{v} / \mathbf{v})\end{array}$ & Final pH & $\begin{array}{c}\text { Cell dry } \\
\text { weight } \\
(\mathbf{g} / \mathbf{l})\end{array}$ & $\begin{array}{c}\text { Protein } \\
(\mathbf{m g} / \mathbf{m l})\end{array}$ & $\begin{array}{c}\text { Activity } \\
(\mathbf{U} / \mathbf{m l})\end{array}$ & $\begin{array}{c}\text { Specific activity } \\
(\mathbf{U} / \mathbf{m g})\end{array}$ & $\begin{array}{c}\text { Yield } \\
(\mathbf{U} / \mathbf{g})\end{array}$ \\
\hline 25 & $9: 1$ & $8.1 \pm 0.11$ & $2.06 \pm 0.41$ & $1.49 \pm 0.1$ & $119.36 \pm 3.84$ & $80.11 \pm 4.66$ & $115.88 \pm 5.14$ \\
\hline $50 *$ & $4: 1$ & $8.2 \pm 0.04$ & $1.61 \pm 0.50$ & $1.14 \pm 0.1$ & $169.34 \pm 51.23$ & $148.54 \pm 34.27$ & $105.18 \pm 17.85$ \\
\hline 75 & $7: 3$ & $8.2 \pm 0.1$ & $1.11 \pm 0.45$ & $1.54 \pm 0.37$ & $224.16 \pm 27.64$ & $145.56 \pm 32.05$ & $135.04 \pm 76.74$ \\
\hline 100 & $3: 2$ & $8.2 \pm 0.04$ & $1.22 \pm 0.62$ & $1.33 \pm 0.1$ & $135.87 \pm 15.88$ & $102.16 \pm 12.67$ & $55.68 \pm 1.04$ \\
\hline
\end{tabular}




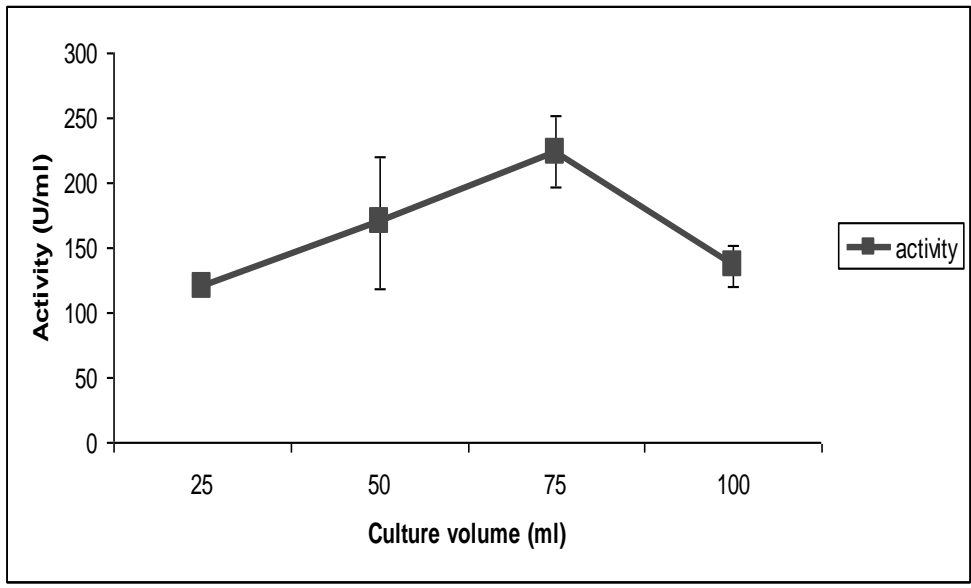

Fig. 6. Effect of different medium volumes on alkaline protease production by $S$. rochei NRC 24.

Effect of medium components on alkaline protease production

In this part of work, the other essential stage in the design of a successful production process, medium formulation, was studied.

Stanbury et al. (1995) stated that there may be medium components that are needed for product formation; however, they are not required for biomass production.

In order to determine the effect of medium components on the production of S. rochei NRC 24 alkaline protease, different preparations of modified PPB medium where one of its components was omitted were studied. Streptomyces rochei NRC 24 cannot totally produce alkaline protease without the presence of peptone, glucose, $\mathrm{MgSO}_{4} \cdot 7 \mathrm{H}_{2} \mathrm{O}$ and $\mathrm{CaCl}_{2}$ in the production medium (Table 10 \& Fig. 7). However, it produced alkaline protease in the absence of $\mathrm{NaCl}$ with less amount $(79.58 \mathrm{U} / \mathrm{ml})$ than the control. On the other hand, the absence of $\mathrm{K}_{2} \mathrm{HPO}_{4}$ from the medium didn't totally influence the production of the enzyme but on the contrary, there was a slight increase in the produced enzyme level (239.39 U/ml). That increase could be attributed to some secondary metabolic processes having a lower tolerance range to inorganic phosphate than vegetative growth (Stanbury et al., 1995). This fact was also confirmed by Liras et al. (1990) who reported that some enzyme syntheses were repressed by phosphate.

Egypt. J. Microbiol. 47 (2012) 
PRODUCTION AND OPTIMIZATION OF ALKALINE ...

TABLE 10. Effect of medium components on the production of $S$. rochei NRC 24 alkaline protease.

\begin{tabular}{|c|c|c|c|c|c|c|}
\hline $\begin{array}{c}\text { Medium } \\
\text { without }\end{array}$ & Final pH & $\begin{array}{c}\text { Cell dry } \\
\text { weight } \\
(\mathbf{g} / \mathbf{l})\end{array}$ & $\begin{array}{c}\text { Protein } \\
(\mathbf{m g} / \mathbf{m l})\end{array}$ & $\begin{array}{c}\text { Activity } \\
(\mathbf{U} / \mathbf{m l})\end{array}$ & $\begin{array}{c}\text { Specific } \\
\text { activity } \\
(\mathbf{U} / \mathbf{m g})\end{array}$ & $\begin{array}{c}\text { Yield } \\
(\mathbf{U} / \mathbf{g})\end{array}$ \\
\hline Control & $8.07 \pm 0.05$ & $1.88 \pm 0.52$ & $3.45 \pm 0.71$ & $231.33 \pm 6.33$ & $67.05 \pm 7.01$ & $123.05 \pm 25.77$ \\
\hline Peptone & $6.77 \pm 0.08$ & $0.663 \pm 0.1$ & $1 \pm 0.42$ & $0.0 \pm 0$ & $0.0 \pm 0$ & $0.0 \pm 0$ \\
\hline Glucose & $8.38 \pm 0$ & $1.604 \pm 0.57$ & $2.07 \pm 1.51$ & $0.0 \pm 0$ & $0.0 \pm 0$ & $0.0 \pm 0$ \\
\hline $\mathrm{MgSO}_{4} .7 \mathrm{H}_{2} \mathrm{O}$ & $8.22 \pm 0.01$ & $1.127 \pm 0.26$ & $2.27 \pm 0.12$ & $0.0 \pm 0$ & $0.0 \pm 0$ & $0.0 \pm 0$ \\
\hline $\mathrm{K}_{2} \mathrm{HPO}_{4}$ & $8.18 \pm 0$ & $1.635 \pm 0.04$ & $2.43 \pm 0.38$ & $239.39 \pm 2.94$ & $98.51 \pm 8.57$ & $146.42 \pm 4.26$ \\
\hline $\mathrm{CaCl}_{2}$ & $8.22 \pm 0$ & $0.758 \pm 0.09$ & $2.38 \pm 0.49$ & $0.0 \pm 0$ & $0.0 \pm 0$ & $0.0 \pm 0$ \\
\hline $\mathrm{NaCl}^{2}$ & $8.08 \pm 0$ & $1.607 \pm 0$ & $1.89 \pm 0.35$ & $79.58 \pm 7.36$ & $42.11 \pm 3.35$ & $49.52 \pm 8.9$ \\
\hline
\end{tabular}

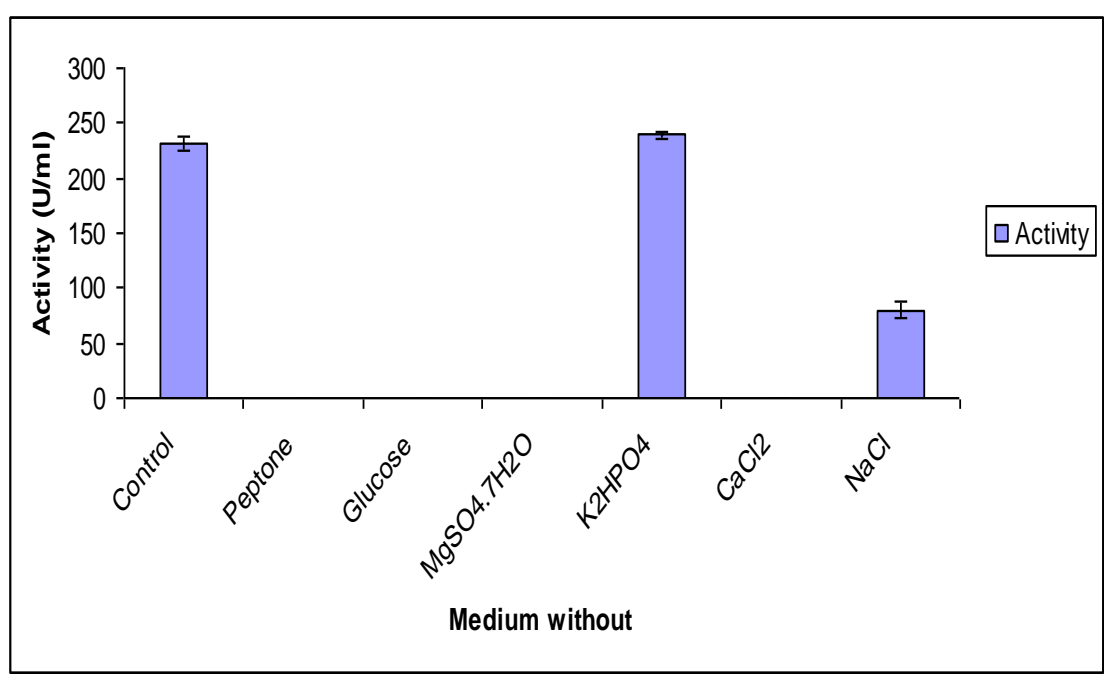

Fig. 7. Effect of medium components on alkaline protease production by $S$. rochei NRC 24. 
Concerning the effect of medium components on either cell growth of $S$. rochei NRC 24 or soluble protein, it was noticed that the elimination of glucose, $\mathrm{MgSO}_{4} .7 \mathrm{H}_{2} \mathrm{O}, \mathrm{K}_{2} \mathrm{HPO}_{4}, \mathrm{NaCl}$ or $\mathrm{CaCl}_{2}$ had a little effect on both cell growth and soluble protein of the fermentation medium that decreased the cell growth by about $64.7 \%$.

Effect of different organic nitrogen sources on alkaline protease production

In many instances cell growth will be faster with a supply of organic nitrogen and a few microorganisms have an absolute requirement for amino acids such that the nitrogen source supplied by fermentation medium would affect enzyme production. Therefore, different organic nitrogen sources in the culture medium were investigated for alkaline protease production by $S$. rochei NRC 24. Casein and peptone were the optimum nitrogen sources for achieving maximal level of alkaline protease production by $S$. rochei NRC 24 (226.25 and $220 \mathrm{U} / \mathrm{ml}$, respectively) (Table 11 \&Fig. 8). In comparison to other substrates, S. rochei NRC 24 could efficiently utilize whey and skimmed milk achieving high level of alkaline protease production (210.15 and $145.16 \mathrm{U} / \mathrm{ml}$, respectively). As a result casein proved to be the most suitable nitrogen source for the enzyme production. On the other hand, soy protein gave the least enzyme production $(25 \mathrm{U} / \mathrm{ml})$. In this respect, similar results were reported by Jayasree et al. (2009) and Dixit \& Pant (2000).

TABLE 11. Effect of different nitrogen sources on the production of $S$. rochei NRC 24 alkaline protease.

\begin{tabular}{|c|c|c|c|c|}
\hline $\begin{array}{l}\text { Nitrogen } \\
\text { source* }\end{array}$ & Final pH & $\begin{array}{c}\text { Total dry } \\
\text { weight } \\
\text { (g/l) }\end{array}$ & $\begin{array}{l}\text { Protein } \\
(\mathrm{mg} / \mathrm{ml})\end{array}$ & $\begin{array}{c}\text { Activity } \\
\text { (U/ml) }\end{array}$ \\
\hline Peptone** & $8.4 \pm 0.11$ & $3.54 \pm 0.38$ & $1.91 \pm 0.5$ & $220 \pm 17.39$ \\
\hline Wheat flour & $5.4 \pm 0.39$ & $11.71 \pm 2.7$ & $1.94 \pm 0.75$ & $1.89 \pm 0.95$ \\
\hline Whey & $6.6 \pm 1.7$ & $12.64 \pm 6.06$ & $4.2 \pm 0.82$ & $201.15 \pm 20.07$ \\
\hline Casein & $8.5 \pm 0.05$ & $2.22 \pm 0.66$ & $2.26 \pm 0.02$ & $226.25 \pm 23.58$ \\
\hline Soy milk & $8.4 \pm 0.08$ & $2.14 \pm 0.06$ & $1.18 \pm 0.27$ & $43.74 \pm 7.77$ \\
\hline Soy flour & $8.6 \pm 0.02$ & $3.06 \pm 0.32$ & $2.26 \pm 0.31$ & $132.83 \pm 26.66$ \\
\hline $\begin{array}{c}\text { Soybean } \\
\text { meal }\end{array}$ & $8.6 \pm 0.22$ & $34.24 \pm 5.96$ & $12.99 \pm 3.43$ & $24.1 \pm 11.08$ \\
\hline $\begin{array}{c}\text { Skimmed } \\
\text { milk }\end{array}$ & $7.7 \pm 0.37$ & n.s. ${ }^{a}$ & $22.01 \pm 1.36$ & $145.16 \pm 20.05$ \\
\hline Oat flakes & 5.9 & n.s. ${ }^{\mathrm{a}}$ & $1.57 \pm 0.04$ & 0.0 \\
\hline
\end{tabular}

* On equal nitrogen basis

** Control

a Not specified

Egypt. J. Microbiol. 47 (2012) 


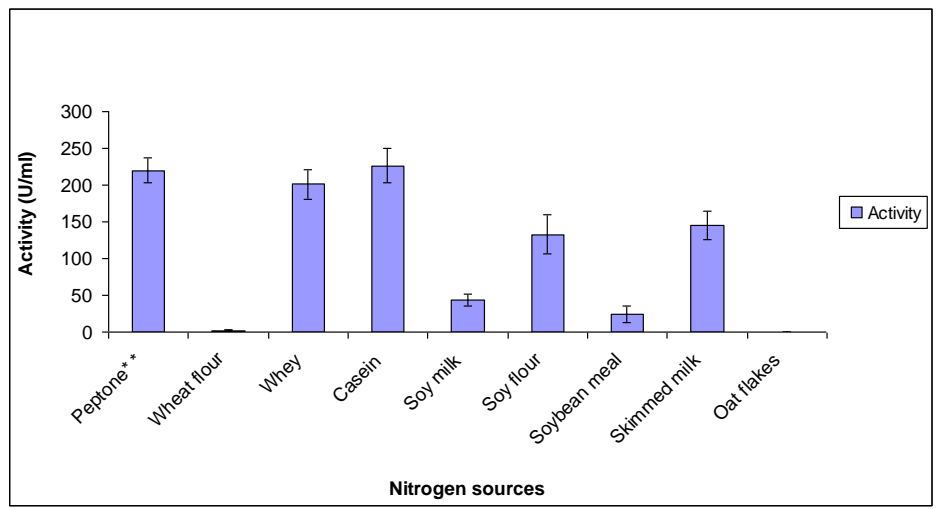

Fig. 8. Effect of different nitrogen sources on alkaline protease production by $S$. rochei NRC 24.

The research also included the effect of different concentrations of casein in the culture medium (Table 12 and Fig. 9). The succeeding experiments were performed using casein at $4 \mathrm{~g} / \mathrm{l}$ concentration in the culture medium. This concentration showed to be the most effective for the enzyme production (239.3 U/ml). This result is in agreement with that obtained by Ramesh et al. (2009).

TABLE 12. Effect of casein concentrations on the production of $S$. rochei NRC 24 alkaline protease.

\begin{tabular}{|c|c|c|c|c|c|c|}
\hline $\begin{array}{c}\text { Casein } \\
\text { concentration } \\
(\mathbf{g} / \mathbf{l})\end{array}$ & Final pH & $\begin{array}{c}\text { Cell dry } \\
\text { weight } \\
(\mathbf{g} / \mathbf{l})\end{array}$ & $\begin{array}{c}\text { Protein } \\
(\mathbf{m g} / \mathbf{m l})\end{array}$ & $\begin{array}{c}\text { Activity } \\
(\mathbf{U} / \mathbf{m l})\end{array}$ & $\begin{array}{c}\text { Specific } \\
\text { activity } \\
(\mathbf{U} / \mathbf{m g})\end{array}$ & $\begin{array}{c}\text { Yield } \\
(\mathbf{U} / \mathbf{g})\end{array}$ \\
\hline 1 & $7.6 \pm 0.11$ & $0.63 \pm 0.07$ & $0.23 \pm 0.15$ & $7.63 \pm 3.1$ & $33.17 \pm 11.48$ & $12.11 \pm 4.48$ \\
\hline 2 & $8.1 \pm 0.11$ & $0.5 \pm 0.08$ & $0.72 \pm 0.09$ & $139.84 \pm 6.28$ & $194.22 \pm 19.76$ & $279.68 \pm 7.9$ \\
\hline $4^{*}$ & $8.4 \pm 0.22$ & $0.91 \pm 0.02$ & $1.16 \pm 0.12$ & $239.3 \pm 7.75$ & $206.03 \pm 9.61$ & $262.67 \pm 7.52$ \\
\hline 6 & $8.1 \pm 0.07$ & $1.14 \pm 0.02$ & $1.64 \pm 0.03$ & $200.68 \pm 10.8$ & $122.37 \pm 6.54$ & $107.34 \pm 8.23$ \\
\hline 8 & $8.1 \pm 0.06$ & $1.79 \pm 0.19$ & $3.18 \pm 0.57$ & $190 \pm 25.12$ & $59.75 \pm 8.52$ & $106.15 \pm 10.16$ \\
\hline
\end{tabular}




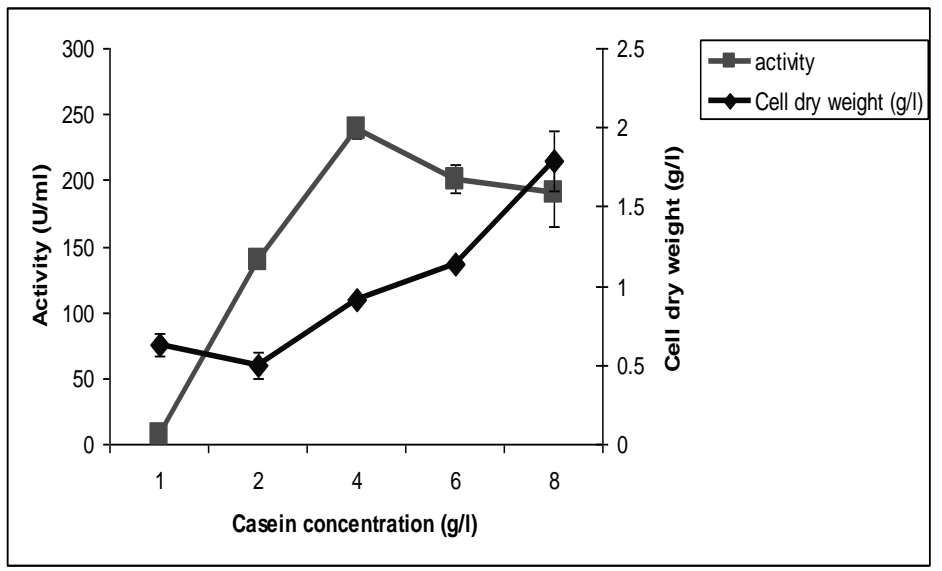

Fig. 9. Effect of casein concentrations on alkaline protease production by $S$. rochei NRC 24.

Optimization of media formulation for alkaline protease production by S. rochei NRC 24 with De Meo design

First optimization step

The design of media optimization is shown in Table 2.The concentration of each variable is shown in Table 3. The results of experimental runs and calculated coefficients for alkaline protease are shown in Tables 13 and 14. The level of alkaline protease activity in eight different runs of the first optimization step varied from 0 to $555.61 \mathrm{U} / \mathrm{ml}$ with an average value of $126.60 \mathrm{U} / \mathrm{ml}$. Similarly there was a wide variation in the amount of soluble protein $(0.94-4.76 \mathrm{mg} / \mathrm{ml})$ as well as specific activity of alkaline protease $(0-231.5 \mathrm{U} / \mathrm{mg})$ of the fermentation trials. From the calculated coefficients of all medium variables, it can be seen that an increase in their level had a positive effect on both enzyme production and its specific activity. However, a negative effect on the biomass dry weight was detected with the increase in casein and $\mathrm{CaCl}_{2}$ concentrations.

\section{Second optimization step}

The level of alkaline protease produced in eight trials of the second optimization step varied between 0 and $73.84 \mathrm{U} / \mathrm{ml}$ with the average enzyme activity $12.78 \mathrm{U} / \mathrm{ml}$. The specific activity of alkaline protease resulted in the second step varied between 0 and $8.07 \mathrm{U} / \mathrm{mg}$ with an average of $1.9 \mathrm{U} / \mathrm{mg}$, which significantly decreased from that of the first step, $51.86 \mathrm{U} / \mathrm{mg}$. However, it was found that there was a marked increase by about 1.93 fold in the average value of cell dry weight of the second optimization step than that of the first step. This indicated that the concentrations of the variables in the second step are more optimized for cellular growth than for alkaline protease production. Consequently, the increase in the medium components level beyond their high levels had a negative effect on alkaline protease production which is obvious from the calculated coefficients for the second optimization step.

Egypt. J. Microbiol. 47 (2012) 
PRODUCTION AND OPTIMIZATION OF ALKALINE ...

TABLE 13. Alkaline protease activity, specific activity, cell dry weight and pH of fermentation in three steps of optimization.

\begin{tabular}{|c|c|c|c|c|c|c|c|c|c|}
\hline \multirow{2}{*}{ Run } & \multicolumn{3}{|c|}{ First step } & \multicolumn{3}{c|}{ Second step } & \multicolumn{3}{c|}{ Third step } \\
\cline { 2 - 9 } & $\begin{array}{c}\text { Cell dry } \\
\text { weight } \\
(\mathbf{g} / \mathbf{l})\end{array}$ & $\begin{array}{c}\text { Activity } \\
(\mathbf{U} / \mathbf{m l})\end{array}$ & $\begin{array}{c}\text { Specific } \\
\text { Activity } \\
(\mathbf{U} / \mathbf{m g})\end{array}$ & $\begin{array}{c}\text { Cell dry } \\
\text { weight } \\
(\mathbf{g} / \mathbf{l})\end{array}$ & $\begin{array}{c}\text { Activity } \\
(\mathbf{U} / \mathbf{m l})\end{array}$ & $\begin{array}{c}\text { Specific } \\
\text { Activity } \\
(\mathbf{U} / \mathbf{m g})\end{array}$ & $\begin{array}{c}\text { Cell dry } \\
\text { weight } \\
(\mathrm{g} / \mathbf{l})\end{array}$ & $\begin{array}{c}\text { Activity } \\
\text { (U/ml) }\end{array}$ & $\begin{array}{c}\text { Specific } \\
\text { Activity } \\
\text { (U/mg) }\end{array}$ \\
\hline 1 & $0.487 \pm 0.10$ & $1.56 \pm 2.7$ & $1.27 \pm 1.9$ & $0.813 \pm 0.26$ & $2.57 \pm 4.45$ & $2.11 \pm 4.32$ & $0.507 \pm 0.07$ & $54.69 \pm 6.03$ & $44.1 \pm 14.31$ \\
2 & $0.19 \pm 0.01$ & $166.06 \pm 20.33$ & $70.36 \pm 23.8$ & $0.957 \pm 0.12$ & $7.48 \pm 12.96$ & $1.23 \pm 1.93$ & $1.306 \pm 0.26$ & $118.13 \pm 2.0$ & $23.07 \pm 2.99$ \\
3 & $1.463 \pm 0.06$ & $0.0 \pm 0.0$ & $0.0 \pm 0$ & $1.02 \pm 0.28$ & $0.0 \pm 0.0$ & $0.0 \pm 0$ & $0.602 \pm 0.02$ & $0.0 \pm 0.0$ & $0.0 \pm 0$ \\
4 & $0.426 \pm 0.04$ & $32.14 \pm 5.36$ & $6.75 \pm 1.34$ & $1.8 \pm 0.05$ & $73.84 \pm 9.03$ & $8.07 \pm 1.1$ & $1.383 \pm 0.06$ & $4.74 \pm 5.0$ & $0.74 \pm 0.81$ \\
5 & $0.413 \pm 0.08$ & $0.55 \pm 0.95$ & $0.59 \pm 0.76$ & $0.45 \pm 0.04$ & $0.0 \pm 0.0$ & $0.0 \pm 0$ & $0.519 \pm 0.04$ & $0.0 \pm 0.0$ & $0.0 \pm 0$ \\
6 & $0.687 \pm 0.24$ & $256.9 \pm 132.91$ & $104.43 \pm 66.98$ & $1.77 \pm 0.09$ & $0.0 \pm 0.0$ & $0.0 \pm 0$ & $1.855 \pm 0.32$ & $87.57 \pm 14.59$ & $14.97 \pm 4.05$ \\
7 & $0.5 \pm 0.4$ & $0.0 \pm 0.0$ & $0.0 \pm 0$ & $1.39 \pm 0.12$ & $3.82 \pm 6.62$ & $2.09 \pm 3.22$ & $1.35 \pm 0.19$ & $0.0 \pm 0.0$ & $0.0 \pm 0$ \\
8 & $1.18 \pm 0.33$ & $555.61 \pm 38.18$ & $231.5 \pm 26.35$ & $2.265 \pm 0.23$ & $14.5 \pm 1.17$ & $1.67 \pm 0.4$ & $2.732 \pm 0.32$ & $200.33 \pm 45.4$ & $45.02 \pm 3.47$ \\
average & 0.68 & 126.60 & 51.86 & 1.31 & 12.78 & 1.9 & 1.28 & 48.31 & 15.2 \\
\hline
\end{tabular}

TABLE 14. Coefficients for each variables of the first, the second and the third optimization steps.

\begin{tabular}{|c|c|c|c|c|c|c|c|}
\hline \multirow{2}{*}{ Coefficient } & \multicolumn{7}{|c|}{ Medium variables } \\
\hline & A & B & $\mathrm{C}$ & $\mathrm{D}$ & $\mathrm{E}$ & $\mathrm{F}$ & G \\
\hline \multicolumn{8}{|l|}{$1^{\text {st }}$ step } \\
\hline $\mathrm{C}_{\mathrm{p}}$ & 126.07 & 20.34 & 76.66 & 20.86 & 76.92 & 55.33 & 53.95 \\
\hline $\mathrm{C}_{\mathrm{s}}$ & 51.4 & 7.7 & 32.27 & 8.17 & 32.44 & 23.92 & 23.75 \\
\hline $\mathrm{C}_{\mathrm{x}}$ & -0.05 & 0.23 & 0.04 & -0.05 & 0.28 & -0.07 & 0.13 \\
\hline \multicolumn{8}{|l|}{$2^{\text {nd }}$ step } \\
\hline $\mathrm{C}_{\mathrm{p}}$ & 11.18 & 10.26 & -8.2 & 9.95 & -8.51 & -5.68 & -7.28 \\
\hline $\mathrm{C}_{\mathrm{s}}$ & 0.85 & 1.06 & -0.96 & 1.07 & -0.95 & -0.12 & -1.17 \\
\hline $\mathrm{C}_{\mathrm{x}}$ & 0.39 & 0.31 & 0.16 & 0.02 & 0.16 & 0.05 & -0.14 \\
\hline \multicolumn{8}{|l|}{$3^{\text {rd }}$ step } \\
\hline $\mathrm{C}_{\mathrm{p}}$ & 44.51 & -6.92 & 13.79 & 6.78 & 27.47 & 35.11 & 21.43 \\
\hline $\mathrm{C}_{\mathrm{s}}$ & 4.96 & -4.55 & -0.99 & 6.48 & 10.04 & 12.06 & 1.04 \\
\hline $\mathrm{C}_{\mathrm{x}}$ & 0.39 & 0.31 & 0.16 & 0.02 & 0.16 & 0.05 & -0.14 \\
\hline
\end{tabular}


Third optimization step

The level of alkaline protease produced in eight trials of the third optimization step varied between 0 and $200.33 \mathrm{U} / \mathrm{ml}$ with the average enzyme activity of $48.34 \mathrm{U} / \mathrm{ml}$. The specific activity of alkaline protease obtained in the third step varied between 0 and $45.02 \mathrm{U} / \mathrm{mg}$ with an average of $15.2 \mathrm{U} / \mathrm{mg}$ which significantly increased from that of the second step $(1.9 \mathrm{U} / \mathrm{mg})$, however, it was still less than that of the first step $(51.86 \mathrm{U} / \mathrm{mg})$. Consequently, the increase in casein level beyond its concentration in the first optimization step $(6 \mathrm{~g} / \mathrm{l}) \mathrm{had}$ a negative effect on alkaline protease production by $S$. rochei NRC 24 . However, the increase in casein concentration had a positive effect on biomass production which could be observed from the average values of cell dry weight in both the second and third optimization steps $(1.31$ and $1.28 \mathrm{~g} / \mathrm{l})$. Similar results were reported by Mehta et al. (2006) in which alkaline protease synthesis by an alkaliphilic actinomycete was repressed by using high concentrations of peptone, yeast extract, glucose, $\mathrm{K}_{2} \mathrm{HPO}_{4}$ and certain amino acids. Mehta et al. (2006) illustrated that repression by reporting that nitrogen sources affected enzyme secretion in case of recently reported actinomycetes (Vinogrodova et al., 2003 for S. cremeus 510 MUG). Complex organic nitrogen sources such as yeast extract and peptone being rich in amino acids and short peptides displayed enzyme repression, when used at higher concentrations. This trend has earlier been shown in case of Bacillus firmus (Moon \& Parulekar, 1991). Catabolite repression of enzyme synthesis was investigated in the presence of high concentration of glucose, inorganic phosphate $\left(\mathrm{K}_{2} \mathrm{PO}_{4}\right)$, nitrogen (yeast extract and peptone) and amino acids (lysine, tyrosine, tryptophan and arginine) (Mehta et al., 2006).

As a consequence, maximal level of alkaline protease $(555.61 \mathrm{U} / \mathrm{ml})$ could be obtained by applying the conditions of the first optimization step as the optimum conditions.

The statistical data of the overall experiments proved that there was a critical limit of stimulation of enzyme production by those components. The results also proved that the applied approach was most effective for optimizing the production of alkaline protease as the production was increased by 2.38 fold.

\section{References}

Abdel-Aziz, M.S., El-Shafei, H.A, Ghaly, M.F. and Hamed, A.A. (2011) Alkaline protease from marine Streptomyces albidflavus and its probable applications. J. Appl. Sci. Res. 7, 897-906.

Ahmed, I., Irfan, M., Nadeem, M., Zia, M.A., Ahmad, B.M. and Iqbal, H. M.N. (2010) Optimization of media and environmental conditions for alkaline protease production using Bacillus subtilis in submerged fermentation process. IJAVMS. 4, 105-113.

Ahmed, S.A. (1994) Biochemical studies on microbial proteolytic enzymes. MSc. Thesis, Department of Biochemistry, Faculty of Agric., Cairo University, Egypt.

Egypt. J. Microbiol. 47 (2012) 
Ahmed, S.A., Al-domany, R.A., El-Shayeb, N.M.A., Radwan, H.H. and Saleh, S.A. (2008) Optimization, immobilization of extracellular alkaline protease and characterization of its enzymatic properties. Res.J. Agri. Biol. Sci. 4, 434-446.

Basavaraj, N.K., Chandrashekhara, S., Shamarez1, A.M., Goudanavar, P.S. and Manvi, F.V. (2010) Isolation and morphological characterization of antibiotic producing actinomycetes. Tropical J. Pharm. Res. 9, 231-236.

Beg, Q.K., Saxena, R.K. and Gupta, R. (2002) De-repression and subsequent induction of protease synthesis by Bacillus mojavensis under fed-batch operations. Process Biochem. 37, 1103-1109.

Chahal, D.S. and Nanda, S.K. (1975) A screening of some actinomycetes for protease production. 41, 427-434.

Dastager, S.G., Dayanand, A., Li, W., Kim, C., Lee, J., Park, D., Tian, X. and Raziuddin, Q.S. (2008) Proteolytic activity from an alkali-thromotolerant Streptomyces gulbargensis sp. nov. Curr. Microbiol. 57, 638-642.

De Azeredo, L.A.I., De Lima, M.B., Coelho, R.R.R. and Freire, D.M.G. (2006a) Thermophilic protease production by Streptomyces sp. 594 in submerged and solidstate fermentations using feather meal. J. Appl. Microbiol. 100, 641-647.

De Azeredo, L.A.I., De Lima, M.B., Coelho, R.R.R. and Freire, D.M.G. (2006b) A low-cost fermentation medium for thermophilic protease production by Streptomyces sp. 594 using feather meal and corn steep liquor. Curr. Microbiol. 53, 335-339.

De Meo, M., Larget, M., Phan-Tan-Luu, R., Mathieu, D. and Dumenil, G. (1985) Application of experimental designs for optimization of medium and culture conditions in fermentation. Bioscience, 4, 99-102.

Dixit, V.S. and Pant, A. (2000) Comparative characterization of two serine endopeptidases from Nocardiopsis sp. NCIM 5124. Biochim. et Biophys. Acta, 1523, 261-268.

Elibol, M. and Moreira, A. (2005) Optimizing some factors affecting alkaline protease production by a marine bacterium Teredinobacter turnirae under solid substrate fermentation. Process Biochem. 40, 1951-1956.

Gessesse, A. and Gashe, B.A. (1997) Production of alkaline protease by an alkaliphilic bacteria isolated from an alkaline soda lake. Biotechnol. Lett. 19, 479-481.

Gupta, R., Beg, Q.K. and Lorenz, P. (2002) Bacterial alkaline proteases: molecular approaches and industrial applications. Appl. Microbiol. Biotechnol. 59, 15-32. 
Gupta, R., Saxena, R.K., Chaturvedi, P. and Virdi, J.S. (1995) Chitinase production by Streptomyces viridificans: its potential in fungal cell wall lysis. J. Appl. Bacteriol. 78, 378-383.

Hames-Kocabas, E.E. and Uzel, A. (2007) Alkaline protease production by an actinomycete MA1-1 isolated from marine sediments. Ann. Microbiol. 57, 71-75.

Jayasree, D., Kumar, D.T.S., Kishor, P.B.K., Lakshmi, M.V. and Narasu, M.L. (2009) Optimization of production protocol of alkaline protease by Streptomyces pulvereceus. Inter Jr.. Sci. Technol. 1, 79-81.

Kanekar, P.P., Nilegaonkar, S.S., Sarnaik, S.S. and Kelkar, A.S. (2002) Optimization of protease activity of alkaliphilic bacteria isolated from an alkaline lake in India. Bioresource Technol. 85, 87-93.

Lazim, H., Mankai, H., Slama, N., Barkallah, I. and Limam, F. (2009) Production and optimization of thermophilic alkaline protease in solid-state fermentation by Streptomyces sp. CN902. J. Ind. Microbiol. Biotechnol. 36, 531-537.

Liras, P., Asturias, J.A. and Martin, J.F. (1990) Phosphate control sequences involved in transcriptional regulation of antibiotic biosynthesis. Trends Biotech. 8, 184-189.

Lowry, O.H., Rosebrough, N.J., Farr, A.L. and Randall, R.J. (1951) Protein measurement with the Folin phenol reagent. J. Biol. Chem. 193, 265-275.

Markl, H. and Bronnenmeier, R. (1985) Mechanical stress and microbial production. In: "Biotechnology. Fundamentals of Biochemical Engineering”, Rehm H.J., Reed G. (Ed.), Vol., 2. pp. 369-392, H. Brauer, VCH Weinheim, Germany.

Mashhadi-Karim, Mohammad, Azin M. and Gargari, S.L.M. (2011) Production of alkaline protease by entrapped Bacillus licheniformis cells in repeated batch process. J. Microbiol. Biotechnol. 21, 1250-1256.

Mehta, V.J., Thumar, J.T. and Singh, S.P. (2006) Production of alkaline protease from an alkaliphilic actinomycete. Bioresource Technol. 97, 1650-1654.

Mitra, P., Chakraverty, R. and Chandra A. (1996) Production of proteolytic enzymes by solid state fermentation-an overview. J. Sci. Ind. Res. 55, 439-442.

Mitsuiki, S., Sakai, M., Moriyama, Y., Goto, M. and Furukawa, K. (2002) Purification and some properties of a keratinolytic enzyme from an alkaliphilic Nocardiopsis sp. TOA-1. Biosci. Biotechnol. Biochem. 66, 164-167.

Moon, S.H. and Parulekar, S.J. (1991) A parametric study of protein production in batch and fed-batch cultures of Bacillus firmus. Biotechnol. Bioeng. 37, 467-483.

Egypt. J. Microbiol. 47 (2012) 
Nascimento, R.P., D'Avila-Levy, C.M., Souza, R.F., Branquinha, M.H., Bon, E.P.S., Pereira-Jr, N. and Coelho, R.R.R. (2005) Production and partial characterization of extracellular proteinases from Streptomyces malaysiensis, isolated from a Brazilian cerrado soil. Arch. Microbiol. 184, 194-198.

Rahman, R.N.Z.A., Geok, L.P., Basri, M. and Salleh, A.B. (2005) Physical factors affecting the production of organic solvent-tolerant protease by Pseudomonas aeruginosa strain K. Bioresource Technol. 96, 429-436.

Ramesh, S., Rajesh, M. and Mathivanan, N. (2009) Characterization of a thermostable alkaline protease produced by marine Streptomyces fungicidicus MML1614. Bioprocess Biosyst. Eng. 32, 791-800.

Rao, M.B., Aparna, M., Tanksale, Mohini, S., Ghatge and Deshpande, V.V. (1998) Molecular and biotechnological aspects of microbial proteases. Microbiol. Mol. Biol. Rev. 62, 597-635.

Roach, P.C.J., O'Reilly, J., Norbertczak, H.T., Hope, R.J., Venter, H., Patching, S.G., Jamshad, M., Stockley, P.G., Baldwin, S.A., Herbert, R.B., Rutherford, N.G., Bill, R.M. and Henderson, P.J.F. (2008) Equipping a research scale fermentation laboratory for production of membrane proteins. In: "Practical Fermentation Technology". Mcneil, B. and Harvey, L.M. (Ed.), pp. 37-68. John Wiley and Sons Ltd, The Atrium, Southern Gate, Chichester, England.

Sepahy, A.A. and Jabalameli, L. (2011) Effect of culture conditions on the production of an extracellular protease by Bacillus sp. isolated from soil sample of Lavizan jungle park. Enzyme Res. 1-7.

Stanbury, P.F., Whitaker, A. and Hall, S.J. (1995) Media for industrial fermentations. In: "Principles of Fermentation Technology". Stanbury, P.F., Whitaker, A. and Hall, S.J. (Ed.), pp. 92-122 Butterworth-Heinemann, Burlington MA 01803,.

Tanaka, H. (1982) Some properties of pseudo cells of plant cells. Biotechnol. Bioeng. 24, 2591-2596.

Thumar, J.T. and Singh, S.P. (2007) Secretion of an alkaline protease from a salttolerant and alkaliphilic Streptomyces clavuligerus strain MIT-1. Braz. J. Microbiol. 38, 766-772.

Tsujibo, H., Miyamoto, K., Hasegawa, T. and Yoshihiko (1990) Purification and characterization of two types of alkaline serine proteases produced by an alkalophilic actinomycete. J. Appl. Bacteriol. 69, 520-529.

Uyar, F., Porsuk, I., Kizil, G. and Yilmaz, E.I. (2011) Optimal conditions for production of extracellular protease from newly isolated Bacillus cereus strain CA15. Eur. Asia J. Bio. Sci. 5, 1-9.

Varela, H., Ferrari, M.D., Belobradjic, L., Weyrauch, R. and Loperena, M.L. (1996) Effect of medium composition on the production by a new Bacillus subtilis isolate of protease with promising unhairing activity. World J. Microbiol. Biotechnol. 12, 643645 . 
Vinogrodova, K.A., Vlasova, I.I., Sharkova, T.S., Dodzin, M.E. and Maksimov, V.N. (2003) L-Glutamate oxidase from Streptomyces cremeus 510 MGU: Effect of nitrogen sources on enzyme secretion. Antibiot. Khimioter, 48, 3-8.

Yeoman, K.H. and Edwards, C. (1997) Purification and characterization of the protease enzymes of Streptomyces thermovulgaris grown in rapemeal-derived media. J. Appl. Microbiol. 82, 149-156.

Young, J.W., Wadeson, A., Glover, D.J., Quincey, R.V., Butlin, M.J. and Kamei, E. (1996) The extracellular acid protease of Yarrowia lipolytica: sequence and $\mathrm{pH}$ regulated transcription. Microbiol. 142, 2913-2921.

(Received 24/4/2012;

accepted 21/6/2012)

Egypt. J. Microbiol. 47 (2012) 


\title{
تحسين إنتاج انزيم البروتييز القلوى بواسطة التخمر المغمور

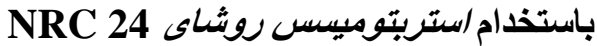

\author{
محمد عبد الفتاح فريد, نجوى أحمد عبدالله,, نيرة أحمد عبدالواحد و أسماء \\ إبراهيم الثاذلى اعلى الفياء \\ قسم كيمياء المنتجات الطبيعية و الميكروبية ــ المركز القومى للبحوث و و *قسم \\ الميكروبيولوجى- كلية العلوم- جامعة عين شمس- القاهرة ـ ـ مصر.
}

\begin{abstract}
يهدف هذا البحث إلى دراسة إنتاج إنزيم البروتييز القلوى وذللك من خلال سلالة

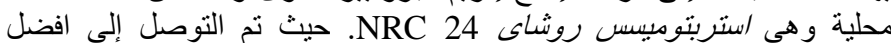

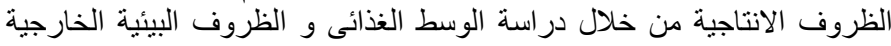

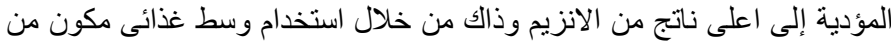

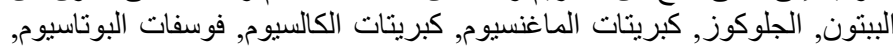

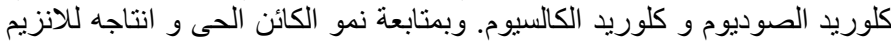

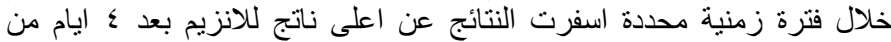

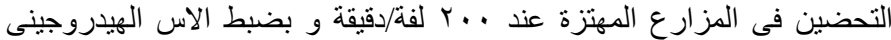

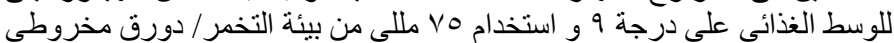

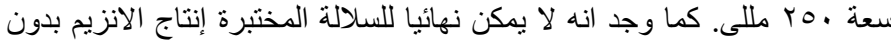

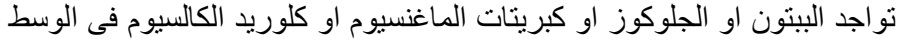

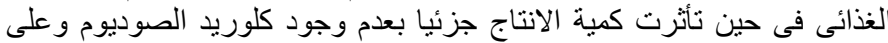

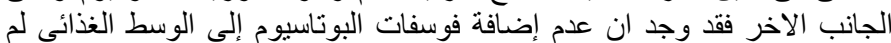

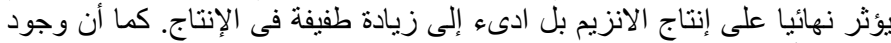

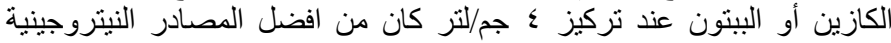

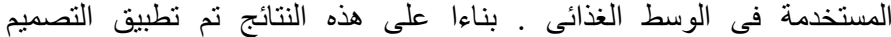

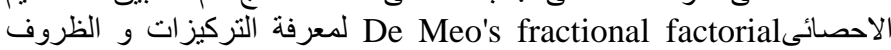

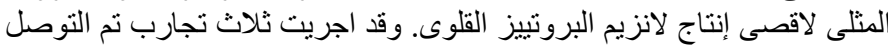

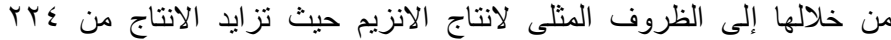

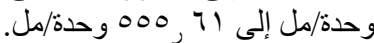

